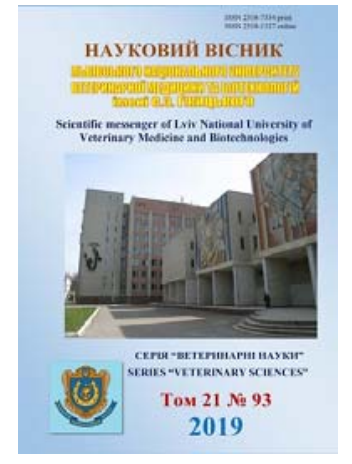

Науковий вісник Дьвівського національного університету ветеринарної медицини та біотехнологій імені С.3. Гжицького.

\author{
Серія: Ветеринарні науки
}

Scientific Messenger of Lviv National University of Veterinary Medicine and Biotechnologies.

Series: Veterinary sciences

\title{
Histological characteristics of accessory adrenal glands of rabbits with different types of autonomous tonus
}

\author{
M.V. Zakrevska, A.M. Tybinka \\ Stepan Gzhytskyi National University of Veterinary Medicine and Biotechnologies Lviv, Ukraine
}

Article info

Received 08.02.2019

Received in revised form 13.03.2019

Accepted 14.03.2019

Stepan Gzhytskyi National University of Veterinary Medicine and Biotechnologies Lviv, Pekarska Str., 50, Lviv, 79010, Ukraine. Tel.: +38-067-454-75-10 E-mail: martazakrevska@gmail.com
Zakrevska, M.V., \& Tybinka, A.M. (2019). Histological characteristics of accessory adrenal glands of rabbits with different types of autonomous tonus. Scientific Messenger of Lviv National University of Veterinary Medicine and Biotechnologies. Series: Veterinary sciences, 21(93), 125130. doi: $10.32718 /$ nvlvet 9322

For the purposes of the adrenal gland's study, 27 four months old male rabbits (Oryctolagus cuniculus) of Termond White breed were selected. Based on electrocardiography and variation pulsometry results, three types of autonomous tonus were determined in animals: sympathicotonia (ST), normotonia (NT) and parasympathicotonia (PS), which formed the basis for the division of animals into three groups. All rabbits were subjected to euthanasia and histological preparations were made from their adrenal glands. Apart from the main adrenal gland, accessory adrenal gland was detected in five purposes animals, including three ST rabbits, one NT rabbit and one PS rabbit. Also, four accessory adrenal glands were revealed in one ST rabbit simultaneously. In fact, these accessory adrenal glands became the main object of the further morphological research. The obtained historical indicators accessory adrenal glands were compared to the ones from various animal groups (CT with NT and CT with PS), as well as to the indicators of the main adrenal gland in each group. Statistical analysis of the received data was performed only in the group of ST animals. Accessory adrenal gland of ST rabbits is represented by two zones: zona glomerulosa and zona fasciculata, the area of which is $52 \%$ and $48 \%$ respectively. In PS and NT rabbits, the glands are formed by zona glomerulosa only. Investigating the accessory adrenal gland's cellular component, it was found that $N T$ rabbits have the largest cell area in zona glomerulosa, while PS rabbits have the smallest one. At the same time, the area of nucleus has the largest values in ST animals and the smallest ones in PS animals likewise. Comparing zona glomerulosa and zona fasciculata in ST rabbits, it was found that cell size differs significantly, while the area of nucleus is almost identical. The nuclear-cytoplasmic ratio in zona glomerulosa cells is the largest for PS rabbits. The smallest ratio values were detected among the NT rabbits. Obviously, ST rabbits occupy an intermediate position. Unlike the main adrenal gland, the cells of accessory adrenal gland are of a smaller size and a denser location of cells in all groups of animals. The conducted studies allow concluding that the typological features of the autonomous tonus affect the morphology of accessory adrenal gland.

Key words: rabbits, accessory adrenal gland, zona glomerulosa, zona fasciculata, sympathicotonic rabbits (ST), normotonic rabbits (NT), parasympatheticontic rabbits (PS).

\section{Гістологічна характеристика додаткових надниркових залоз кролів 3 різними типами автономного тонусу}

\author{
М.В. Закревська, А.М. Тибінка
}

Львівський національний університет ветеринарної медицини та біотехнологій імені С.3. Гжицького, м. Львів, Украӥна

Для дослідження надниркових залоз відібрали 27 кролів-самиів (Oryctolagus cuniculus) породи Термонська біла, віком 4 місяці. У тварин, на основі проведення електрокардіографії та варіаційної пульсометрії, встановили три типи автономного тонусу: сим- 
патотонію (СТ), нормотонію (НТ) та парасимпатикотонію (ПС), які стали основою для поділу тварин на три групи. Всіх кролів піддали евтаназії, а з їхніх надниркових залоз виготовили гістологічні препарати. У п'яти досліджених тварин, окрім основних надниркових залоз, виявлено додаткові надниркові залози. Серед них: 3 кролі-СТ, 1 кріль-НТ та 1 кріль-ПС. При иьому в одного кроля-СТ одночасно виявлено чотири додаткові надниркові залози. Власне додаткові надниркові залози і стали основним об 'єктом подальших морфологічних досліджень. Отримані гістологічні показники додаткових надниркових залоз порівняли між групами тварин (СТ з НТ та СТ з ПС), а також з показниками основних надниркових залоз в межах кожної групи. Статистичний аналіз цифрових даних проводили лише в групі тварин-симпатотоніків. Додаткові надниркові залози кролів-СТ представлені двома зонами: клубочковою та пучковою, площа яких становить 52\% та 48\% відповідно. У кролів-ПС та НТ залози сформовані лише клубочковою зоною. При досліджені клітинного компоненту додаткової надниркової залози встановлено, щзо в клубочковій зоні кроля-НТ площа клітин є найбільшою, а в кроля-ПС - найменшою. Поряд з тим площа ядра мала найбільші значення в тварин-СТ, а найменше - також в ПС. При порівнянні клубочкової та пучкової зон у кролів-СТ виявлено, щуо розміри клітин суттєво відрізняються, а площуа ядер є майже однаковою. Ядерно-цитоплазматичне відношення в клітинах клубочкової зони є найбільшим в кроля-ПС. Найменші його значення належать тварині-НТ. Відповідно кролі-СТ займають проміжне місце. Клітини додаткової надниркової залози, порівняно з основною наднирковою залозою, характеризуються меншими розмірами у всіх групах тварин, а також щүільнішим розташуванням. На основі проведених досліджень можна стверджувати, щзо типологічні особливості автономного тонусу впливають на морфологію додаткових надниркових залоз.

Ключові слова: кролі, додаткова надниркова залоза, клубочкова зона, пучкова зона, симпатотоніки (СТ), нормотоніки (НT), парасимпатикотоніки (ПС).

\section{Вступ}

Надниркові залози як орган були відкриті Бартоломео Еустахіем у 1563 році в людини (Eustachius, 1563), їхня функція та будова вивчалася протягом багатьох років, і у 1765 році Morgagni поряд 3 наднирковими залозами виявив та описав додаткові надниркові залози. Вони розміщуються поряд з основною наднирковою залозою та оточені власною сполучнотканинною капсулою. У додаткових надниркових залозах завжди виявляють клубочкову зону, іноді пучкову зону. Мозкова та сітчаста зони відсутні (Cesta et al., 2014). Наявність додаткових надниркових залоз характерна для багатьох видів тварин: коней (Ahmadpanahi, 2007), кіз (Pathak et al., 2015), собак та котів (Juodžiukynienè, 2014; Herbach et al., 2016), мишей та щурів (Cesta et al., 2014), а також людей (Morgagni, 1820; Mendez et al., 2006; Afuwape et al., 2009; Niveditha et al., 2014). Marino та ін., 2012 спостерігали ектопію додаткових надниркових залоз у інші органи, зокрема статеві залози обох статей (Ozel et al., 2007; Rabie et al., 2013; Sangeeta et al., 2014). Також повідомлялося (Afuwape et al., 2009), що додаткові надниркові залози можуть бути епіцентром розвитку новоутворень, a Sarah et al., 2017 виявили тканину надниркової залози у грижовому мішку.

Проте сьогодні $є$ мінімум даних про морфометричні характеристики додаткових надниркових залоз кролів, а також не вивчено особливості структури цих залоз у тварин з різними типами автономного тонусу. Вирішення цих завдань і стало метою даної роботи.

\section{Матеріал і методи досліджень}

За принципом аналогів відібрано 27 кролів-самців (Oryctolagus cuniculus) породи Термонська біла, віком 4 місяці, яких за допомогою електрокардіографічного та варіаційно-пульсометричного досліджень (Баевский та ін., 1984) поділили на групи: парасимпатикотоніки (ПС) - 3 тварини, нормотоніки (НТ) - 5 тварин та симпатотоніки (СТ) - 19 тварин. Тварин піддали евтаназії та відібрали надниркові залози для гістологічного дослідження. Органи фіксували у рідині Буе- на, проводили через висхідний ряд спиртів та поміщали в парафінові блоки, з яких на мікротомі МC-2 виготовляли гістозрізи товщиною 7 мкм. Після висушування гістозрізи фарбували гематоксиліном Маєра та еозином, а також азаном за Гейденгайном (Romeys, 1954). На гістопрепаратах в окремих тварин (три тварини-СТ, одна тварина-НТ та одна тварина-ПС) виявлено додаткові надниркові залози. При цьому в одного кроля-СТ в межах основної надниркової залози було 4 додаткових надниркових залози. Всі вони піддані морфометричному аналізу. Дослідження основної та додаткової надниркових залоз проводилося паралельно, проте акцент робився на вивчення додаткових надниркових залоз.

Препарати вивчали під мікроскопом Leica DM2500 з камерою Leica DFC450C. Для морфометричних досліджень використовували програмне забезпечення Aperio Image Scope.

Під час морфометрії фронтального зрізу додаткових надниркових залоз визначали такі показники: площу залози, товщину клубочкової зони, площу пучкової зони, кількість клітин на 1000 мкм², площу клітин та їх ядер, ядерно-цитоплазматичне відношення (ЯЦВ). При цьому показники кролів-СТ брали за основу і з ними порівнювали показники двох інших груп тварин. Отримані результати також порівнювали 3 показниками основних надниркових залоз.

Статистична обробка результатів проводилася лише у групі кролів-СТ за допомогою програми "StatPlus2008".

\section{Результати та їх обговорення}

Загалом з 27 дослідних тварин додаткові надниркові залози виявлено в 5 кролів, тобто у 19\% випадків. Що стосується частоти виникнення даних структур в межах окремих груп, то у кролів-ПС - 33\%, НТ - 20\% i CТ - 16\%. Частота виявлення додаткових надниркових залоз у кролів $є$ нижчою порівняно з іншими видами тварин. Так, за даними Herbach та ін., 2016 ці структури трапляються у $30 \%$ кішок та у $50 \%$ собак.

Локалізація додаткових надниркових залоз може мати кілька варіантів: вони можуть розміщувалися 
поодиноко в паренхімі кіркового шару основної залози (рис. 1) або поряд 3 нею, в довколишній сполучній тканині (рис. 2). Також додаткові залози можуть розшаровувати основну залозу (рис. 3), а іноді через незавершену інкапсуляцію мають спільну з основною

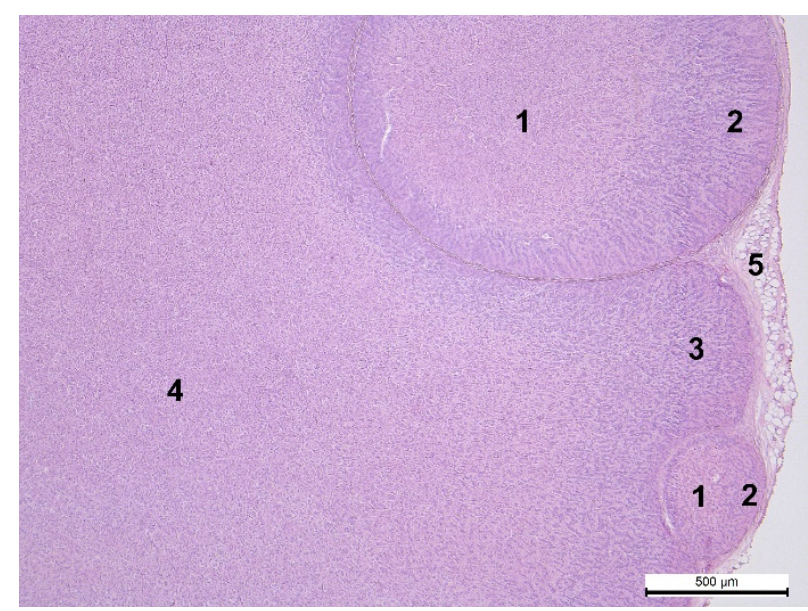

Рис. 1. Додаткові надниркові залози в складі основної надниркової залози кроля-СТ: 1 - пучкова зона додаткової надниркової залози, 2 - клубочкова зона додаткової надниркової залози, 3 - клубочкова зона основної надниркової залози, 4 - пучкова зона основної надниркової залози, 5 - капсула.

Гематоксилін та еозин

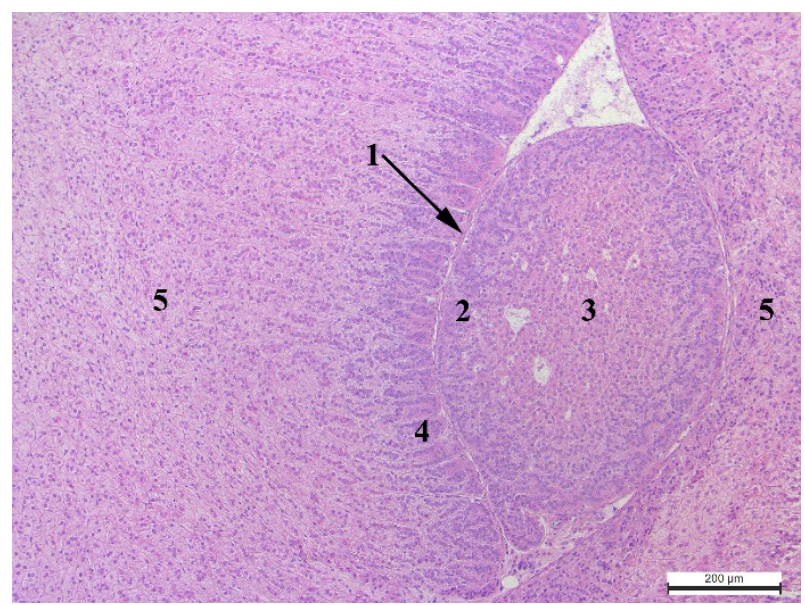

Рис. 3. Додаткова надниркова залоза в розшарованій паренхімі основної надниркової залози кроля-СТ: 1 - капсули додаткової та основної надниркових залоз, 2 - клубочкова зона додаткової надниркової залози, 3 - пучкова зона додаткової надниркової залози, 4 - клубочкова зона основної надниркової залози, 5 - пучкова зона основної надниркової залози. Гематоксилін та еозин

Розмір додаткових надниркових залоз коливається в значному діапазоні (таб. 1). Більші за площею залози траплялися у тварин-СТ. Вони переважали кроляНТ на 716070,7 мкм², а ПС - на 723659,67 мкм².

У структурі досліджених додаткових надниркових залоз представлені лише окремі фрагменти кіркової зони основної надниркової залози. Важливо зазначити, що клубочкова зона добре виражена у всіх додат- залозою пучкову зону (рис. 4). Подібне розміщення додаткових надниркових залоз описане у роботах Ahmadpanahi, 2007; Pathak et al., 2015. Їх також виявляли у мозковій зоні основної надниркової залози (Herbach et al., 2016).

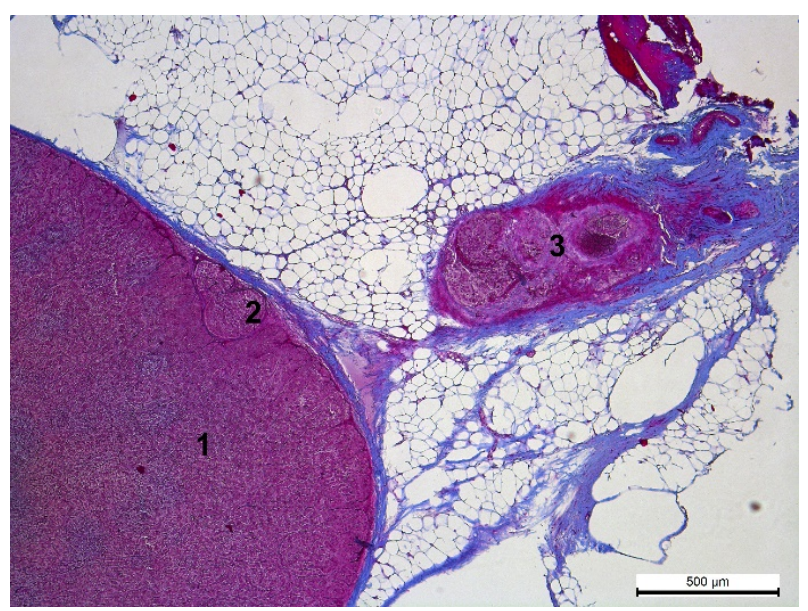

Рис. 2. Основна та додаткові надниркові залози кроля-СТ: 1 - паренхіма основної надниркової залози, 2 - додаткова надниркова залоза у товщі основної надниркової залози, 3 - додаткова надниркова залоза поряд з основною наднирковою залозою. Азан за Гейденгайном

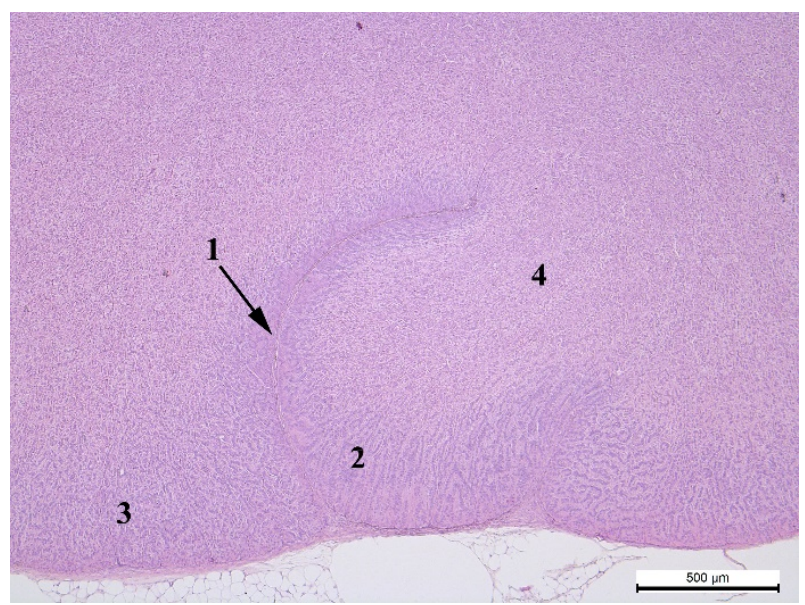

Рис. 4. Додаткова надниркова залоза в паренхімі основної надниркової залози кроля-СТ: 1 - капсула додаткової залози, 2 - клубочкова зона додаткової надниркової залози, 3 - клубочкова зона основної надниркової залози, 4 - пучкова зона спільна для додаткової та основної надниркових залоз. Гематоксилін та еозин

кових надниркових залозах. Поряд з тим ці залози не мають мозкової та сітчастої зон, а пучкова зона траплялася лише у кролів-СТ (рис. 5, 6). Це, на нашу думку, пов'язано з особливостями формування цих структур, оскільки в період ембріонального розвитку мозкова зона формується 3 нервової трубки і заглиблюється у ектодермальну кіркову зону. Внаслідок цього, кіркова зона розщеплюється і $з$ неї можуть формува- 
тися додаткові надниркові залози (Niveditha et al., 2014). Поряд 3 тим окремі автори (Hummel, 1958; Sass, 1983) повідомляють, що додаткові надниркові залози можуть формуватися впродовж всього життя, а Commichau у 1927 році описував їх появу як компенсаторний механізм при старінні. Однак це не узгоджується $з$ даними Herbach et al., 2016, які виявляли ці залози у котів та собак до шестимісячного віку. Дос- ліджені нами додаткові надниркові залози також відібрано від молодих тварин (віком 4 місяці), що підтверджує їхнє ембріональне походження.

Наявність додаткових надниркових залоз, за даними Cesta et al., 2014, є аномаліями розвитку, які не впливають на функціонування основної надниркової залози, оскільки виконують спільну з нею функцію.

\section{Таблиця 1}

Морфометричні показники додаткових надниркових залоз кролів

\begin{tabular}{|c|c|c|c|}
\hline \multirow{2}{*}{ Показник } & \multicolumn{3}{|c|}{ Групи кролів } \\
\hline & CT & HT & $\Pi \mathrm{\Pi C}$ \\
\hline Площа зрізу залози, мкм² & $748866,7 \pm 252166,5$ & 25207 & 32796 \\
\hline Кількість клітин клубочкової зони на площі 1000 мкм² & $11,0 \pm 0,5$ & 9,1 & 14,7 \\
\hline Кількість клітин пучкової зони на площі 1000 мкм² & $6,8 \pm 0,5$ & & \\
\hline Товщина клубочкової зони, мкм & $147,8 \pm 28,9$ & & \\
\hline Площа пучкової зони, мкм² & $361745,6 \pm 122917,1$ & & \\
\hline Площа клітини клубочкової зони, мкм² & $88,0 \pm 7,4$ & 104,7 & 66,3 \\
\hline Площа ядра клітини клубочкової зони, мкм² & $30,0 \pm 1,1$ & 29,0 & 24,7 \\
\hline ЯЦВ клітин клубочкової зони & $0,58 \pm 0,03$ & 0,43 & 0,63 \\
\hline Площа клітини пучкової зони, мкм² & $138,2 \pm 13,1$ & & \\
\hline Площа ядра клітини пучкової зони, мкм² & $30,4 \pm 1,5$ & 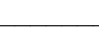 & \\
\hline ЯЦВ клітин пучкової зони & $0,32 \pm 0,25$ & 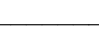 & 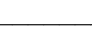 \\
\hline
\end{tabular}

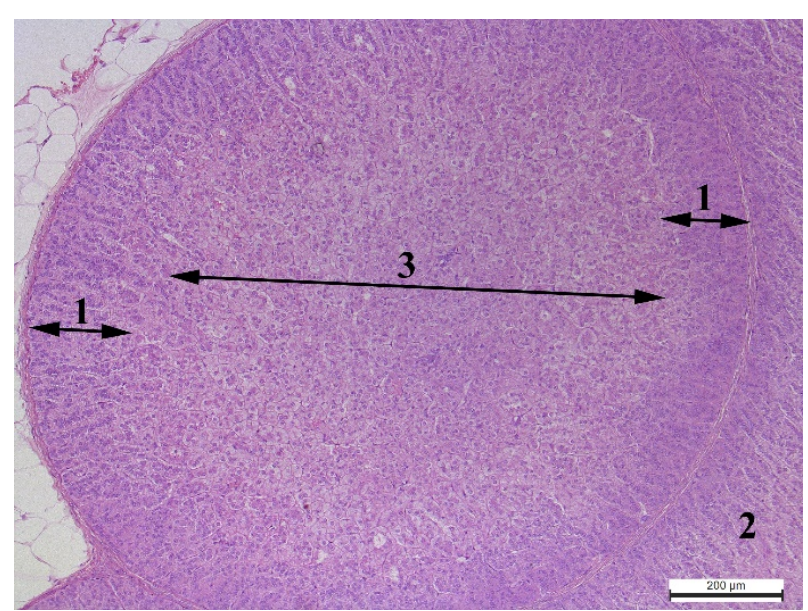

Рис. 5. Додаткова надниркова залоза кроля-СТ $з$ двома зонами: 1 - клубочкова зона додаткової надниркової залози, 2 - клубочкова зона основної надниркової залози, 3 - пучкова зона додаткової надниркової залози. Гематоксилін та еозин

При досліджені клітинного компоненту додаткових надниркових залоз (рис. 7, 8), встановлено, що

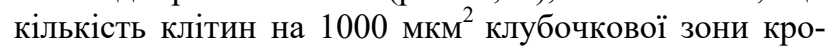
лів-СТ є меншою від кроля-ПС на 3,7 одиниць та більшою від кроля-НТ на 1,9 одиниць. У основній наднирковій залозі даний показник $є$ меншим, тобто іiі клітини розташовані менш щільно, ніж в додатковій наднирковій залозі.

Розміри клітин також відрізняються в кролів різних груп. Найбільшу площу клітин клубочкової зони додаткової надниркової залози виявлено у кроля-НТ. Тварини-СТ та ПС поступаються відповідно на

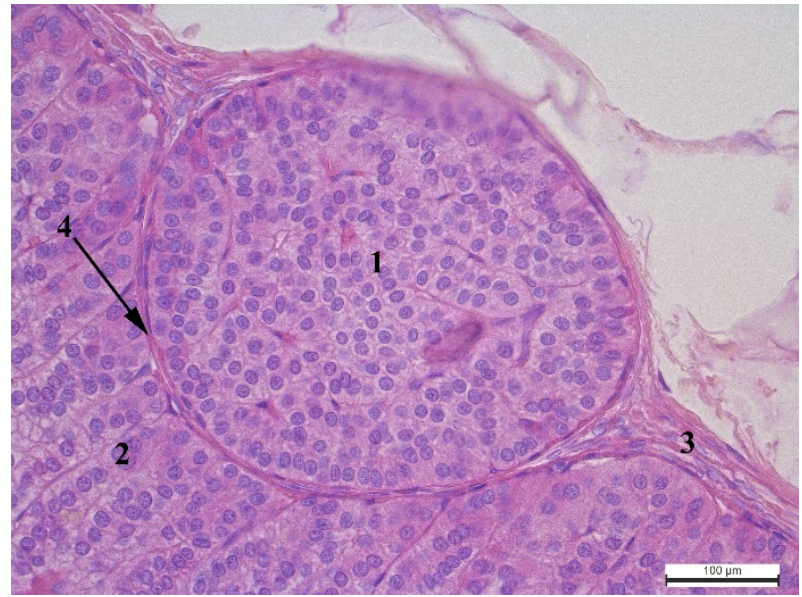

Рис. 6. Додаткова надниркова залоза кроля-ПС з однією зоною: 1 - клубочкова зона додаткової надниркової залози, 2 - клубочкова зона основної надниркової залози, 3 - капсула основної надниркової залози, 4 - капсула додаткової надниркової залози. Гематоксилін та еозин

\section{6,7 мкм² та 38,4 мкм².}

Щодо площі ядер клітин клубочкової зони, то в додаткових надниркових залозах цей показник має найбільші значення у кролів-СТ. Незначно (на 1,0 мкм ${ }^{2}$ ) поступається їм кріль-НТ і суттєво меншим (на 5,3 мкм²) досліджуваний показник є в кроля-ПС.

Ядерно-цитоплазматичне відношення в клітинах клубочкової зони найвище у кроля-парасимпатика. У групі-СТ даний показник $є$ меншим на 0,05 мкм $^{2}$ та займає проміжне положення, оскільки найменше значення відповідає кролю-НТ, який поступається СТ на 0,15 мкм $^{2}$. 


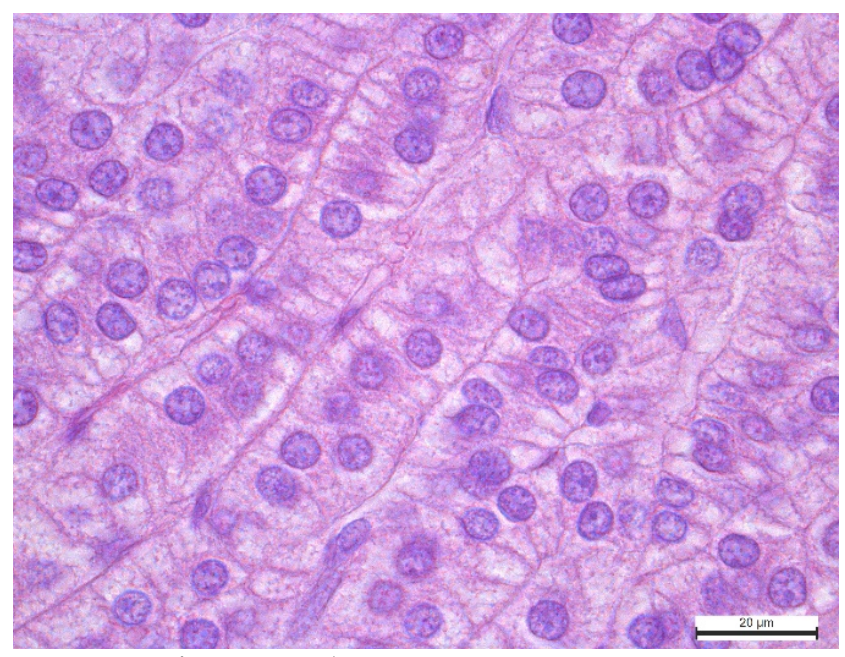

Рис. 7. Клітини клубочкової зони додаткової надниркової залози кроля-СТ. Гематоксилін та еозин

Пучкова зона виявлялася лише у кролів-СТ. Проте стверджувати, що наявність чи відсутність цієї зони пов'язана з типом автономного тонусу, ми не можемо, оскільки у кролів-НТ та ПС додаткова надниркова залоза траплялася лише в одного представника групи. Оскільки пучкова зона розташована в центрі додаткової надниркової залози, то замість товщини визначали іiі площу. При цьому, встановили, що дана зона займає 48\% площі всієї додаткової надниркової залози. Відповідно на клубочкову зону припадає 52\% площі залози.

Пучкова зона додаткової надниркової залози, порівняно з основною залозою, характеризується меншими розмірами клітин та їхніх ядер, проте більшим показником ядерно-цитоплазматичного відношення та щільнішим розташуванням клітин.

Аналізуючи морфометричні дані, помітили, що спостерігається морфо-функціональна компенсація та залежність кількості та ЯЦВ клітин клубочкової зони від їхніх лінійних розмірів, що проявляється у тварин всіх груп. При збільшенні площі клітин виявлено зменшення їхньої кількості у тварин-НТ, а при зменшенні площі - збільшення кількості клітин у ПС. Це пов'язано $з$ накопиченням біологічноактивних речовин в цитоплазмі клітин і призводить до відповідних морфо-функціональних перебудов.

\section{Висновки}

Додаткові надниркові залози виявлено в 19\% всіх досліджених тварин. У перерахунку на окремі групи це становило: в кролів-ПС - 33\%, НТ - 20\% і СТ $16 \%$. Додаткові надниркові залози кролів-СТ представлені двома зонами: клубочковою (52\% площі залози) та пучковою (48\% площі залози), а кролів-ПС та НТ лише клубочковою. Щільність розташування клітин клубочкової зони кролів-СТ та НТ $є$ майже однаковою, значно меншою вона $є$ у кроля-ПС. ЯЦВ клітин клубочкової зони має найбільше значення в кроляПС, проміжне - СТ та найменше - в НТ. Отже, у структурі додаткових надниркових залоз проявляєть-

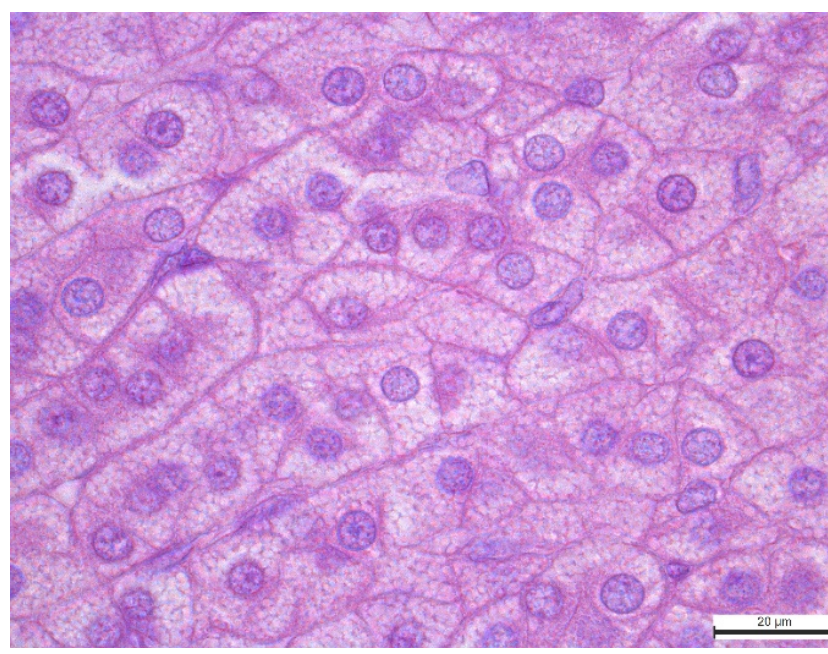

Рис. 8. Клітини пучкової зони додаткової надниркової залози кроля-СТ. Гематоксилін та еозин

ся вплив типологічних особливостей автономного тонусу.

Перспективи подальших досліджень. Дослідити ультраструктурні особливості додаткових надниркових залоз у кролів з різними типами автономного тонусу. 3'ясувати фактори, які обумовлюють появу додаткових надниркових залоз.

\section{References}

Afuwape, O., Ladipo, J.K., Ogun, O., Adeleye, J., \& Irabor, D. (2009). Pheochromocytoma in an accessory adrenal gland: a case report. Cases Journal, 2(8), 6271. doi: 10.4076/1757-1626-2-6271.

Ahmadpanahi, J. (2007). Anatomical and histological studies of accessory adrenal nodules in Caspian miniature horses. Turkish Journal of Veterinary and Animal Sciences, 31(4), 275-278. http://journals.tubitak.gov.tr/veterinary/issues/vet-0731-4/vet-31-4-11-0608-8.pdf.

Baevs'kij, R.M., Kirilov, O.I., \& Kleckin, S.Z. (1984). Matematicheskij analiz serdechnogo ritma pri stresse. Moskva: Nauka (in Russian).

Cesta, M.F., Malarkey, D.E., Herbert, R.A., \& Brix, A. (2014). Nonneoplastic Lesion Atlas - National Toxicology Program. Toxicologic Pathology, 42(2), 458-460. doi: 10.1177/0192623313517304.

Commichau, K. (1927). Über die knotigen Hyperplasien der Nebennierenrinde bei Hunden, sogenannten corticalen Hypernephrome. Journal of Cancer Research and Clinical Oncology, 25, 253-290. doi: 10.1007/bf02122321.

Eustachius, B. (1563). Opuscula Anatomica. Venice:Vincentius Luchinus Excudebat.

Herbach, N., Wiele, K., Konietschke, U., \& Hermanns, W. (2016). Pathologic Alterations of Canine and Feline Adrenal Glands. Open Journal of Pathology, 6, 140-153. doi: 10.4236/ojpathology.2016.63017.

Hummel, K.P (1958). Accessory adrenal cortical nodules in the mouse. Anat Rec., 132(3), 281-296. doi: 10.1007/978-3-642-96720-7_3. 
Juodžiukynienè, N., Aniulienė, A., Sabeckienė, J., \& Valančiūtè, A. (2014). The histopathological evaluation of dogs adrenal glands. Veterinarija ir Zootechnika, 66(88), 12-19. https://vetzoo.lsmuni.lt/ data/vols/2014/66/pdf/juodziukyniene.pdf.

Marino, G., Quartuccio, M., Rizzo, S., lo Presti, V., \& Zanghì, A. (2012). Ectopic adrenal tissue in equine gonads: morphofunctional features. Turkish Journal of Veterinary and Animal Sciences, 36(5), 560-565. doi: 10.3906/vet-1104-15.

Mendez, R., Tellado, M.G., Somoza, I., Liras, J., Sanchez-Abuin, A., Pais, E., \& Vela, D. (2006). Ectopic Adrenal Tissue in the Spermatic Cord in Pediatric Patients: Surgical Implications. Pediatric Urology International Braz J Urol, 32(2), 202-207. doi: 10.1590/S1677-55382006000200013.

Morgagni, G.B. (1820). De Sedibus et causis morborum per anatomem indagatis. Apud M. C. Compère.

Niveditha, S.R., Manjula, C.P., \& Sudarshan, B.K.G. (2014). Accessory Adrenal Cortical Tissue: An Incidental Finding in Hernial Sac. Journal of Evidence Based Medicine and Healthcare, 1(3), 157-159. doi: 10.18410/jebmh/2014/26.

Ozel, S.K., Kazez, A., \& Akpolat, N. (2007). Presence of ectopic adrenocortical tissues in inguinoscrotal region suggests an association with undescended testis.
Pediatr Surg Int. 23, 171-175. doi: 10.1007/s00383006-1826-1.

Pathak, S.K., Farooqui, M.M., Singh, D., \& Gupta, V. (2015). Histomorphological studies of the accessory adrenal nodules in prenatal goats. The Indian Journal of Small Ruminants, 21(1), 152-154. doi: 10.5958/0973-9718.2015.00014.8.

Rabie, M.E., Shah, M.T., Jamil, S., \& Al-Shraim, M.M. (2013). Adrenal rests associated with ectopic testis in an adult: Clinical significance. Urol Ann, 5(4), 302304. doi: 10.4103/0974-7796.120307.

Romeys, B.V. (1954). Mikroskopicheskaya tehnika. Moskva: Izdatel'stvo inostrannoj literatury (in Russian).

Sangeeta, M., Parthiban, R., \& Vinila, B.H.S. (2014). Ectopic adrenal rests in testis - a case report. International Journal of Basic and Applied Medical Sciences, 4(1), 42-44.

Sarah, S.K., Velilla, R.E., \& Shurbaji, M.S. (2017). Adrenal cortical heterotopia in an inguinal hernia sac of an adult: A casereport and literature review. Human Pathology, 8, 13-15. doi: 10.1016/j.ehpc.2016.08.007.

Sass, B. (1983). Accessory Adrenocortical Tissue, Mouse. Endocrine System. Monographs on Pathology of Laboratory Animals. Heidelberg: Springer (in Berlin). doi: 10.1007/978-3-642-96720-7 3. 